\title{
Coronary deaths during Midsummer festival in Finland: miseries of long, light nights
}

\author{
Simo Näyhä ${ }^{1}$ (1)
}

Received: 27 March 2020 / Accepted: 26 March 2021 / Published online: 21 April 2021

(c) The Author(s) 2021

\begin{abstract}
This paper examines whether the anomalous summer peak in deaths from coronary heart disease (CHD) in Finland could be attributed to adverse effects of the Midsummer festival and alcohol consumption during the festival. Daily deaths from CHD and alcohol poisoning in Finland, 1961-2014, that occurred during the 7 days centering on Midsummer Day were analysed in relation to deaths during 14 to 4 days before and 4 to 14 after Midsummer Day. Daily counts of deaths from CHD among persons aged 35-64 years were regressed on days around the Midsummer period by negative binomial regression. Mortality from CHD was highest on Midsummer Day (RR 1.25 (95\% confidence interval 1.12-1.31), one day after the peak in deaths from alcohol poisonings. RR for CHD on Midsummer Day was particulary high $(\mathrm{RR}=1.43 ; 1.09-1.86)$ in the 2000 s, $30 \%$ of deaths being attributable to that day. In conclusion, the anomalous and prominent summer peak in deaths from CHD in Finland is an adverse consequence of the Midsummer festival. The most likely underlying reason is heavy alcohol consumption during the festival period, especially on Midsummer Eve. In the 2000s, one third of deaths from CHD on Midsummer Day are preventable.
\end{abstract}

Keywords Coronary heart disease $\cdot$ Mortality $\cdot$ Alcohol $\cdot$ Holidays $\cdot$ Midsummer

\section{Introduction}

Mortality from coronary heart disease (CHD) among the working-aged population in Finland shows an anomalous bi-seasonal pattern with a conspicuous peak in early summer (June) along with a second peak in winter [1]. There is only one incidental report of a similar seasonal pattern from the Nordic countries [2]. An effect of summer heat is unlikely, since the mean temperature in June in Finland is no higher than $15^{\circ} \mathrm{C}$, which is the temperature of lowest mortality in this area [3]. Deaths from CHD were therefore analysed on a daily basis to see if the high June mortality could be attributed to the Midsummer festival (Saturday between June 20th and $26^{\text {th }}$ ) and especially to the heavy alcohol consumption commonly associated with it [4]. In case such an association exists, it would offer an opportunity for prevention.

Simo Näyhä

simo.nayha@oulu.fi

1 Center for Environmental and Respiratory Health Research, University of Oulu, P.O. Box 5000, FI-90014 Oulu, Finland

\section{Methods}

The daily counts of deaths among persons aged 35-64 years in Finland during the period 1961-2014 in which CHD had been recorded as the underlying cause were obtained from Statistics Finland. CHD had been coded as ICD 7 code 420 in 1961-1968, ICD 8 codes 410-414 in 1969-1986, ICD 9 codes 410-414 in 1987-1995 and ICD 10 codes I20-I25 in 1996-2014. Daily deaths from CHD were compared with those from accidental alcohol poisonings (coded respectively as E880, E860, E851 and X45), which were used as an indicator of heavy alcohol consumption. The diagnosis of CHD was based on a medical or forensic autopsy in $31 \%, 47 \%, 56 \%, 68 \%$ and $83 \%$ of the deaths in the $1960 \mathrm{~s}$, 1970s, 1980s 1990s and 2000s, respectively. The diagnosis of alcohol poisoning was based on autopsy in practically all cases. Only deaths among persons resident in Finland were included. The respective populations were obtained from population statistics.

Daily mortality rates and their $95 \%$ confidence intervals (CI) were first calculated for all 29 day periods from 14 days before to 14 days after Midsummer Day. The 29 day period was selected because it was short enough to rule out any 
seasonal effects. The counts of deaths on -3 to +3 days around the Midsummer Day were compared with daily counts during -14 to -4 and +4 to +14 days around the Midsummer Day which was considered as a period long enough to serve as reference. Negative binomial regression was used to allow for extra-Poisson variation. The results were expressed in terms of mortality rates per 1000,000 person-days, rate ratios, rate differences and fractions attributable to each day. Since Midsummer Day is a Saturday, which in itself increases mortality from CHD [1], an adjustment was made for weekdays. To assess the effect of the steep decline of CHD mortality in Finland since the 1970s, an adjustment was also made for time periods (in classes 1961-1969, 1970-1979, 1980-1989, 1990-1999 and 2000-2014) and was complemented by a time-stratified analysis. The entire seasonal pattern of CHD over the year was shown in terms of weekly mortality rates. The calculations were performed using R software, version 3.50 (http:// www.Rproject.org).

\section{Results}

The upper part of Fig. 1 shows that mortality from CHD increased sharply in late June (week 25) and was followed by a winter peak in December (week 52). A close-up of daily mortality on \pm 14 days around Midsummer Day (two lower parts of Fig. 1) shows a marked increase in coronary deaths on Midsummer Day, while deaths from alcohol poisoning increased one day before that, i.e. on Midsummer Eve. Compared with mortality during the reference periods (3.83 per 1000,000 person-days), mortality increased consistently up to $5.03 / 1000,000$ (by $31 \%$ ) on Midsummer Day and declined consistently towards the end of the holiday period (Table 1). Mortality adjusted for weekdays and time periods still showed an excess of $25 \%$ on Midsummer Day. Adjusted mortality on Midsummer Eve and two days before that also exceeded the reference rate, as did mortality on three days following the Midsummer Day.

One fifth of the deaths that occurred on Midsummer Day were attributable to that day itself, independently of it being a Saturday (Table 1). The respective fractions attributable to other days during the holiday period ranged from 7 to $19 \%$, the fraction being $15 \%$ for the entire 7 day Midsummer period.

There was a sharp decline in CHD mortality since the 1970 s, from 7.23 to 1.75 per 1000,000 person-days in the 2000s (Table 2). Consistently with that, the absolute risk attributable to the Midsummer period declined from 1.45 to 0.19 per 1000,000 person-days, the relative excess reducing from 21 to $12 \%$. Along with declining mortality, the relative excess mortality on Midsummer Day remained elevated, especially since the 1980 s (40\% to $76 \%$ ). In the 2000 s, $30 \%$
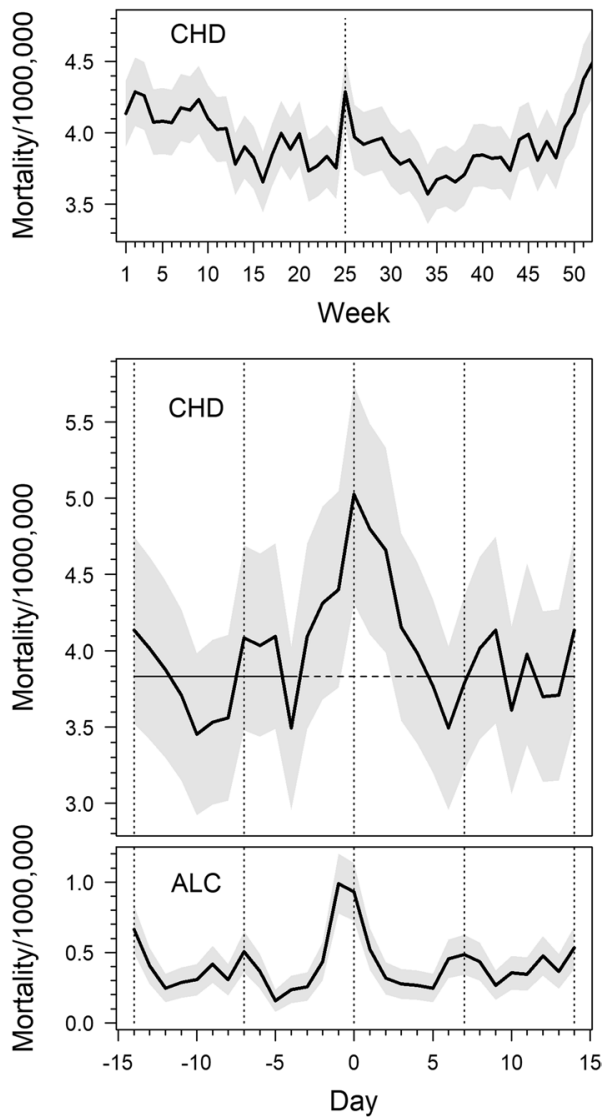

Fig. 1 The upper figure shows weekly mortality from coronary heart disease (CHD) during an average year and the two lower ones daily mortalities from CHD and alcohol poisoning (ALC) during Midsummer Day \pm 14 days (Midsummer Day marked by 0). Shaded areas indicate 95\% confidence bands. The horizontal line shows mortality from CHD during the reference period. Men and women aged 35-64 years, 1961-2014. All mortalities expressed as deaths per 1000,000 person-days

of the deaths on Midsummer Day were attributable to that special day.

\section{Discussion}

This study shows that the prominent June peak in mortality from CHD among the working aged population, which has not been reported from other Nordic countries, is an adverse consequence of the Finnish Midsummer festival. Celebrated since pagan times, originally to mark the summer solstice and later to commemorate the feast of St. John, it continues to be a major holiday in Scandinavia. A recent report from Sweden found an increase of acute myocardial infarctions at Midsummer, but the rise was moderate and the association with alcohol consumption remained less substantiated [5]. In Finland, Midsummer is an all-weekend festival marked by travel to lakeside summer cottages, going to sauna, swimming, revelry, eating and very often excessive 
Table 1 Mortality from coronary heart disease around Midsummer holiday, 1961-2014

\begin{tabular}{|c|c|c|c|c|c|c|c|}
\hline & \multicolumn{2}{|c|}{ No. of deaths } & \multirow{2}{*}{$\begin{array}{l}\text { Mortal- } \\
\text { ity/1000,0000 } \\
\text { person-days }\end{array}$} & \multirow{2}{*}{$\begin{array}{l}\mathrm{RD} / 1000,000 \text { person- } \\
\text { days }\end{array}$} & \multirow[t]{2}{*}{ Crude RR } & \multirow[t]{2}{*}{ Adjusted $^{\mathrm{a}} \mathrm{RR}$} & \multirow{2}{*}{$\begin{array}{l}\text { Attributable fraction } \\
\text { (\%) (crude/adjusted) }\end{array}$} \\
\hline & Sum & Mean/day & & & & & \\
\hline Reference period ${ }^{\mathrm{b}}$ & 8523 & 7.17 & $3.83(3.71-3.96)$ & 0 & 1.00 & 1.00 & \\
\hline $\begin{array}{l}\text { Whole Midsummer } \\
\text { period }^{\mathrm{c}}\end{array}$ & 3179 & 8.41 & $4.49(4.25-4.74)$ & $0.66(0.54-0.79)$ & $1.17(1.10-1.25)$ & $1.18(1.13-1.23)$ & $14.7 / 15.0$ \\
\hline $\begin{array}{l}\text { Wednesday before } \\
\text { Midsummer }\end{array}$ & 414 & 7.67 & $4.10(3.49-4.71)$ & $0.26(-0.22-1.00)$ & $1.07(0.92-1.25)$ & $1.08(0.96-1.21)$ & $6.5 / 7.1$ \\
\hline $\begin{array}{l}\text { Thursday before } \\
\text { Midsummer }\end{array}$ & 436 & 8.07 & $4.31(3.68-4.95)$ & $0.48(-0.03-1.24)$ & $1.13(0.97-1.31)$ & $1.18(1.05-1.32)$ & $11.1 / 14.9$ \\
\hline $\begin{array}{l}\text { Friday, Midsummer } \\
\text { Eve }\end{array}$ & 445 & 8.24 & $4.40(3.76-5.05)$ & $0.57(0.05-1.34)$ & $1.15(0.99-1.34)$ & $1.23(1.09-1.37)$ & $13.0 / 18.5$ \\
\hline $\begin{array}{l}\text { Saturday, Midsummer } \\
\text { Day }\end{array}$ & 508 & 9.41 & $5.03(4.31-5.75)$ & $1.19(0.60-2.04)$ & $1.31(1.13-1.52)$ & $1.25(1.12-1.38)$ & $23.7 / 19.8$ \\
\hline $\begin{array}{l}\text { Sunday after Mid- } \\
\text { summer }\end{array}$ & 485 & 8.98 & $4.80(4.11-5.49)$ & $0.97(0.40-1.78)$ & $1.25(1.08-1.45)$ & $1.19(1.07-1.33)$ & $20.1 / 16.0$ \\
\hline $\begin{array}{l}\text { Monday after Mid- } \\
\text { summer }\end{array}$ & 471 & 8.72 & $4.66(3.98-5.34)$ & $0.83(0.27-1.63)$ & $1.22(1.05-1.41)$ & $1.16(1.04-1.29)$ & $17.8 / 13.5$ \\
\hline $\begin{array}{l}\text { Tuesday after Mid- } \\
\text { summer }\end{array}$ & 420 & 7.78 & $4.16(3.54-4.77)$ & $0.32(-0.17-1.06)$ & $1.08(0.93-1.26)$ & $1.15(1.03-1.29)$ & $7.8 / 13.2$ \\
\hline $\begin{array}{l}\text { Midsummer } \\
\text { Day } \pm 14 \text { days }\end{array}$ & 11,702 & 7.47 & 3.99 & & & & \\
\hline
\end{tabular}

Risk difference $(\mathrm{RD})$ and crude and adjusted risk ratios $(\mathrm{RR})$ relative to the reference period, and attributable fraction of deaths by day

${ }^{a}$ Adjusted for weekdays and time periods

${ }^{\mathrm{b}} 14$ to 4 days before and 4 to 14 days after Midsummer Day

${ }^{\mathrm{c}}$ Three days before and three days after Midsummer Day

drinking. During the week preceding Midsummer, alcohol sales triples. As summer holidays often start at Midsummer, there is no obligation to return to work after the festival [4]. In peoples' minds, Midsummer signifies long, light nights and has a symbolic meaning related to sexuality and fertility.

The most likely explanation for the high mortality from CHD at Midsummer is excessive alcohol consumption, as shown by the successive peaks in fatal alcohol poisonings and coronary deaths on Midsummer Eve and Midsummer Day. The Eastern pattern of drinking which concentrates on weekends and holidays and is also typical of Finland, causes cardiac conduction disturbances, depressed cardiac performance and supraventricular arrhythmias, even in persons without apparent heart disease [6, 7]. In long-time alcohol abusers, acute alcohol ingestion reduces the threshold for ventricular arrhythmias with possibly fatal consequences and may predispose to thrombosis after the drinking binge [8]. Sudden coronary deaths following alcohol ingestion may also occur in people without pre-existing CHD [9]. Acute alcohol consumption also decreases heart rate variability and increase the risk of cardiac death, both in patients with CHD and the general population [10].

Other factors exist that could increase mortality at Midsummer. Sauna bathing is considered safe, even for patients suffering from CHD, but combined with alcohol consumption, it will increase the risk of arrhythmias and sudden death, and together with sweating during long sauna sessions it causes dehydration and haemoconcentration, thus predisposing to thrombosis [11]. The habit of rapid cooling-off in cold water after sauna and doing this repeatedly between the sessions, causes sudden increases in blood pressure and may lead to a rupture of an arterioclerotic plaque, thrombosis and myocardial infarction [12]. In cold water, the simultaneous facial immersion and the cold shock via the skin lead to conflicting chronotropic stimuli from parasympathetic and sympathetic systems, which may trigger arrhythmias and sudden death [13].

Addititional factors include excessive eating, especially salted fish, which easily causes fluid retention among patients suffering from heart failure [14] and could increase the risk of death. Long travels to summer cottages involve physical and emotional triggers that may precipitate acute attacks of CHD [15]. The long geographical distances in this area may prevent timely hospital admission, which may be crucial in case of acute coronary attacks.

The strength of the study is the long time period studied, which allowed an assessment of absolute and relative excess mortalities around Midsummer during the steep decline of CHD since the 1970s. Despite lowering of the absolute mortality attributable to Midsummer, the relative excess remains 
Table 2 Mortality from coronary heart disease around Midsummer holiday by periods

\begin{tabular}{|c|c|c|c|c|c|c|c|}
\hline \multirow[t]{2}{*}{ Days } & \multicolumn{2}{|c|}{ No. of deaths } & \multirow{2}{*}{$\begin{array}{l}\text { Mortal- } \\
\text { ity/1000,0000 } \\
\text { person-days }\end{array}$} & \multirow{2}{*}{$\begin{array}{l}\mathrm{RD} / 1000,000 \text { person- } \\
\text { days }\end{array}$} & \multirow[t]{2}{*}{ Crude RR } & \multirow[t]{2}{*}{ Adjusted $^{\mathrm{a}} \mathrm{RR}$} & \multirow{2}{*}{$\begin{array}{l}\text { Attributable fraction } \\
\text { (\%) (crude/adjusted) }\end{array}$} \\
\hline & Sum & Mean/day & & & & & \\
\hline \multicolumn{8}{|l|}{ 1961-1969 } \\
\hline Reference period ${ }^{\mathrm{b}}$ & 1944 & 9.82 & $6.34(6.04-6.64)$ & 0 & 1 & 1 & \\
\hline Midsummer period $^{\mathrm{c}}$ & 702 & 11.14 & $7.20(6.63-7.76)$ & $0.86(0.59-1.12)$ & $1.14(1.04-1.24)$ & $1.14(1.04-1.25)$ & $11.9 / 12.4$ \\
\hline Midsummer Day & 123 & 13.67 & $8.83(7.17-10.48)$ & $2.49(1.13-3.84)$ & $1.39(1.14-1.68)$ & $1.28(1.03-1.57)$ & $28.2 / 28.6$ \\
\hline $\begin{array}{l}\text { Midsummer } \\
\text { Day } \pm 14 \text { days }\end{array}$ & 2646 & 10.14 & 6.55 & & & & \\
\hline \multicolumn{8}{|l|}{ 1970-1979 } \\
\hline Reference period ${ }^{\mathrm{b}}$ & 2159 & 10.90 & $6.88(6.59-7.18)$ & 0 & 1 & 1 & \\
\hline Midsummer period $^{\mathrm{c}}$ & 832 & 13.21 & $8.34(7.76-8.91)$ & $1.45(1.17-1.73)$ & $1.21(1.12-1.31)$ & $1.21(1.12-1.31)$ & $17.4 / 17.6$ \\
\hline $\begin{array}{l}2 \text { days before Mid- } \\
\text { summer Day }\end{array}$ & 110 & 14.00 & $8.84(7.29-10.38)$ & $1.95(0.70-3.21)$ & $1.28(1.07-1.53)$ & $1.36(1.09-1.67)$ & $22.1 / 22.1$ \\
\hline $\begin{array}{l}\text { Midsummer } \\
\text { Day } \pm 14 \text { days }\end{array}$ & 2991 & 11.46 & 7.23 & & & & \\
\hline \multicolumn{8}{|l|}{ 1980-1989 } \\
\hline Reference period ${ }^{\mathrm{b}}$ & 1622 & 8.19 & $4.51(4.28-4.73)$ & 0 & 1 & 1 & \\
\hline Midsummer period ${ }^{\mathrm{c}}$ & 622 & 9.87 & $5.43(4.99-5.87)$ & $0.93(0.71-1.14)$ & $1.14(1.04-1.24)$ & $1.21(1.10-1.33)$ & $17.0 / 17.3$ \\
\hline $\begin{array}{l}\text { one day before Mid- } \\
\text { summer Day }\end{array}$ & 111 & 12.33 & $6.78(5.52-8.05)$ & $2.28(1.24-3.32)$ & $1.52(1.24-1.82)$ & $1.76(1.39-2.22)$ & $33.6 / 43.3$ \\
\hline $\begin{array}{l}\text { Midsummer } \\
\text { Day } \pm 14 \text { days }\end{array}$ & 2244 & 8.60 & 4.73 & & & & \\
\hline \multicolumn{8}{|l|}{ 1990-1999 } \\
\hline Reference period $^{\mathrm{b}}$ & 989 & 5.00 & $2.43(2.28-2.58)$ & 0 & 1 & 1 & \\
\hline Midsummer period $^{\mathrm{c}}$ & 375 & 5.95 & $2.89(2.60-3.18)$ & $0.47(0.32-0.61)$ & $1.19(1.06-1.34)$ & $1.20(1.06-1.35)$ & $16.1 / 16.4$ \\
\hline Midsummer Day & 54 & 6.00 & $2.91(2.14-3.69)$ & $0.49(-0.14-1.12)$ & $1.20(0.90-1.56)$ & $1.40(1.00-1.92)$ & $16.7 / 28.4$ \\
\hline $\begin{array}{l}\text { Midsummer } \\
\text { Day } \pm 14 \text { days }\end{array}$ & 1364 & 5.23 & 2.54 & & & & \\
\hline \multicolumn{8}{|l|}{ 2000-2014 } \\
\hline Reference period $^{\mathrm{b}}$ & 1227 & 3.72 & $1.70(1.60-1.80)$ & 0 & 1 & 1 & \\
\hline Midsummer period $^{\mathrm{c}}$ & 435 & 4.24 & $1.89(1.70-2.08)$ & $0.19(0.11-0.28)$ & $1.11(0.99-1.25)$ & $1.12(1.00-1.25)$ & $10.2 / 10.5$ \\
\hline Midsummer Day & 80 & 5.33 & $2.44(1.88-3.01)$ & $0.74(0.27-1.21)$ & $1.43(1.12-1.81)$ & $1.43(1.09-1.86)$ & $30.3 / 30.0$ \\
\hline $\begin{array}{l}\text { Midsummer } \\
\text { Day } \pm 14 \text { days }\end{array}$ & 1662 & 3.82 & 1.75 & & & & \\
\hline
\end{tabular}

Risk difference (RD) and crude and adjusted risk ratios (RR) relative to the reference period, and attributable fraction of deaths by day

${ }^{a}$ Adjusted for weekdays and time periods

b 14 to 4 days before and 4 to 14 days after Midsummer Day

${ }^{\mathrm{c}}$ Three days before and three days after Midsummer Day

elevated, as does the preventable fraction of deaths. These trends may have been affected by the increasing number of autopsies and consequent variation in the reliability of death certificates. A limitation of the study is the lack of individual-based data on drinking habits, diet and behavioral patterns during the holiday period. One might argue that the elevated mortality at Midsummer only reflects harvesting of frail individuals who would soon die anyway. This should decrease mortality after the festival, but no such decline was seen here.

The Finnish data show that the risk of adverse cardiac events during holidays can greatly exceed that presupposed by the traditional notion of "holiday heart syndrome" which mainly consists of benign supraventricular arrhythmias following alcohol consumption [6, 7]. The public health gain that could be achieved by prevention is limited by shortness of the risk period, but still an estimated $30 \%$ of coronary deaths on Midsummer Day and 10\% during the entire festival period are preventable, which is useful information for planning pre-emptive measures at this particular time.

Author contributions SN conceived the study idea, conducted all data analyses and wrote the manuscript. 
Funding Open access funding provided by University of Oulu including Oulu University Hospital.

Code Availability The $\mathrm{R}$ code is available from the author on request.

Data Availability The data are confidential and cannot be shared.

\section{Declarations}

Conflicts of interest The author declares that he has no competing interest.

Ethical Approval This is an observational study and no ethical approval is required.

Open Access This article is licensed under a Creative Commons Attribution 4.0 International License, which permits use, sharing, adaptation, distribution and reproduction in any medium or format, as long as you give appropriate credit to the original author(s) and the source, provide a link to the Creative Commons licence, and indicate if changes were made. The images or other third party material in this article are included in the article's Creative Commons licence, unless indicated otherwise in a credit line to the material. If material is not included in the article's Creative Commons licence and your intended use is not permitted by statutory regulation or exceeds the permitted use, you will need to obtain permission directly from the copyright holder. To view a copy of this licence, visit http://creativecommons.org/licenses/by/4.0/.

\section{References}

1. Näyhä S. Short and medium-term variations in mortality in Finland. A study on cyclic variations, annual and weekly periods and certain irregular variations in mortality in Finland during the period 1868-1972. Scand J Soc Med. 1981;1(21):1-101.

2. Jensen F. [No title]. Nord Med 1959:1050-1.

3. Ruuhela R, Jylhä K, Lanki T, Tiittanen P, Matzarakis A. Biometeorological assessment of mortality related to exptreme temperatures in Helsinki region, Finland, 1972-2014. Int J Environ Res Public Health. 2017;14:E944. https://doi.org/10.3390/ijerph1408 0944.
4. Mäkelä $\mathrm{O}$, Martikainen $\mathrm{P}$, Nihtilä E. Temporal variation in deaths related to alcohol intoxication and drinking. Int $\mathrm{J}$ Epidemiol. 2005;34:765-71.

5. Mohammad MA, Karlsson S, Haddad J, Cederberg B, Jernberg T, Lindahl B, Fröbert O, Koul S, Erlinge D. Christmas, national holdays, sport events, and time factors as triggers of acute myocardial infarction: SWEDEHEART observational study 1998-2013. BMJ. 2018;363:k4811. https://doi.org/10.1136/bmj.k4811.

6. Ettinger PO, Wu CF, De La Cruz C Jr, Weisse AB, Ahmed SS, Regan TJ. Arrhythmias and the "Holiday Heart": alcohol-associated cardiac rhythm disorders. Am Heart J. 1978;95(5):555-62.

7. Tonelo D, Providência R, Goncalves K. Holiday heart syndrome revisited after 34 years. Arg Bras Cardiol. 2013;101:183-9.

8. McKee M, Britton A. The positive relationship between alcohol and heart disease in eastern Europe: potential physiological mechanisms. J Royal Soc Med. 1998;91:402-27.

9. Wannemethee G, Shaper AG. Alcohol and sudden cardiac death. Brit Heart J. 1992;68:443-8.

10. Romanowich M, Schmidt JE, Bostwick JM, Mrazek DA, Karpnyak VM. Changes in heart rate variability associated with acute alcohol consumption: current knowledge and implications for practice and research. Alcohol Clin Exp Res. 2011;35:1092-105.

11. Hannuksela ML, Ellehham S. Benefits and risks of sauna bathing. Am J Med. 2001;110:118-26.

12. Imai Y, Nobuoka S, Nagashima J, et al. Acute myocardial infarction induced by alternating exposure to heat in a sauna and rapid cooling in cold water. Cardiology. 1998;90:299-301.

13. Shattock MJ, Tipton MJ. "Autonomic conflict": a different way to die during cold water immersion? J Physiol. 2012;590:3219-30.

14. Gudmundsson K, Lyngå P, Karlsson H, Rosenqvist M, Braunschweig F. Midsummer Eve in Sweden: a natural fluid challenge in patients with heart failure. Eur Heart J. 2011;13:1172-7.

15. Kop WJ, Vingerhoets A, Kruithof GJ, Gottdiener JS. Risk factors for myocardial infarction during vacation travel. Psychosom Med. 2003;65:396-401.

Publisher's Note Springer Nature remains neutral with regard to jurisdictional claims in published maps and institutional affiliations. 